\title{
Sirenomelia Associated with VACTERL and VACTERL-H Syndrome
}

\author{
Sirenomelia Asociaciada con Síndrome de VACTERL y VACTERL-H
}

\author{
Tanya Todorova Kitova ${ }^{1}$; Ekaterina Hristova Uchikova ${ }^{2}$; Peter Angelov Uchikov ${ }^{3} \&$ Borislav Dimitrov Kitov $^{4}$
}

KITOVA, T. T.; UCHIKOVA, E. H.; UCHIKOV, P. A. \& KITOV, B. D. Sirenomelia associated with VACTERL and VACTERL-H syndrome. Int. J. Morphol., 38(3):793-798, 2020.

SUMMARY: Sirenomelia or mermaid syndrome is an extremely rare congenital lethal malformation with a frequency between 1.5 and 4.2 per 1000000 pregnancies. The association of sirenomelia with the VACTERL association is very rare, with twenty cases reported in the literature and only two cases with VACTERL-H. We present two cases of sirenomelia, type I and type II associated with VACTERL-H and VACTERL syndromes and we review the literature. First time pregnancy women aged 15 and 40 years, without harmful habits and diseases, where between 25-27 gestational week (GW) the prenatal study identifies malformative fetus and the pregnancy is interrupted by medical evidence. The fetopathological examination in the first case identified sirenomelia type I associated with myelomeningocele, hydrocephalus, anal imperforation, single umbilical artery, bilateral renal agenesis, ureteral and bladder agenesis, tracheo-esophageal fistule, agenesis of external genitals, monkey fold of the left palm of the hand - VACTERL-H. In the second case, where genetic testing is normal, sirenomelia type II associated with agenesis of external genitalia, anal imperforation, myelomeningocele, dolichocrania, macroglossia, low set ears, left preauricular skin tag, long philtrum, lung hypoplasia, split cadiac apex, single umbilicalis artery, blind end colon, hepatomegaly, accessory spleen, polycystic horseshoe kidney, uterine and vaginal agenesis, presence of two ovaries and duodenal stenosis - VACTERL association. This two cases, lead us to believe that sirenomelia and the VACTERL association are probably different manifestations of a pathogenetic process leading to disorders of blastogenesis at different levels during embryonic development.

KEY WORDS: VACTERL association; VACTERL-H; Sirenomelia; Embryonic development; Genetic study; Congenital malformation.

\section{INTRODUCTION}

Sirenomelia or mermaid syndrome is an extremely rare congenital lethal malformation with a frequency between 1.5 and 4.2 per 1000000 pregnancies (Orioli et al., 2011). The anomaly is characterized by joints of the lower limbs or one leg, hypoplasia or agenesis of the genital organs and kidneys with no bladder, single umbilical artery, abnormalities of the spine and skeletons (Källén et al., 1992; Turgut et al., 2017).

Less commonly, lung hypoplasia, diaphragmatic hernia and cardiac abnormalities are observed (Isik Kaygusuz et al., 2016). According to Stocker \& Heifetz (1987) sirenomelia has 7 types: I - all the bones of the thigh and leg are present; II - one fibula; III - missing fibulae; IV - partially fused femurs and fully fused fibulae; V - partially fused femurs; VI - one femur and fibula; VII - one femur and missing fibula.
We present two cases of sirenomelia, type I and type II associated with VACTERL-H and VACTERL syndromes and we review the literature.

\section{CASES REPORT}

Case 1. Nesuplementirane with folic acid, primigravida of woman at age 15 , with low socioeconomic status, was admitted to the Clinic of Obstetrics and Gynecology, University Hospital "St. George", Plovdiv, Bulgaria with progredient abortion. The prenatal ultrasound examination revealed a malformative fetus and the MRI - hydrocephalus and defects in the lower spine (Fig. $1 \mathrm{~B}$ ). This gives reason to complete the abortion in 20 gestational week (GW). The procedures followed were approved by the institutional

\footnotetext{
${ }^{1}$ Department of Anatomy, Histology and Embryology, Faculty of Medicine, Medical University-Plovdiv, Bulgaria.

${ }^{2}$ Clinic of Obstetrics and Gynecology, University Hospital "St. George ", Plovdiv, Bulgaria.

${ }^{3}$ Department of Surgery, Faculty of Medicine, Medical University-Plovdiv, Bulgaria.

${ }^{4}$ Department of Neurosurgery, Faculty of Medicine, Medical University Plovdiv, Bulgaria.
} 

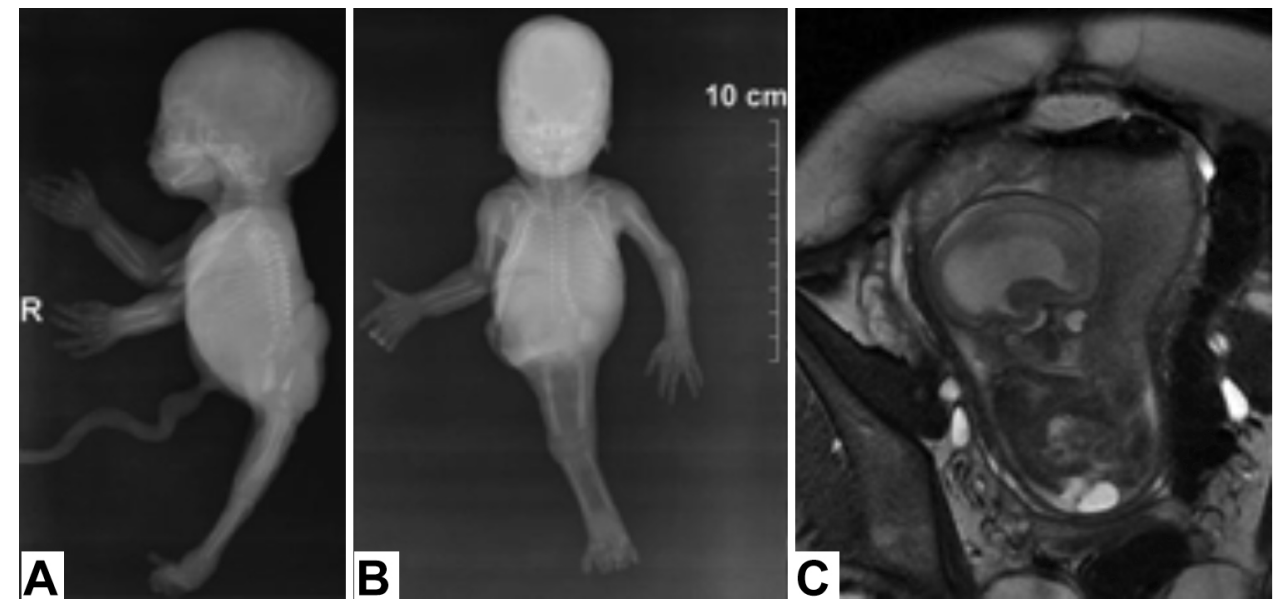

Fig. 1. Sirenomelia. A and B / Radiography (face and profile). One lower limb with bones for two lower limbs and feet; C / Prenatal MRI visualizes the available hydrocephalus and defects of the lower spine and spinal cord.
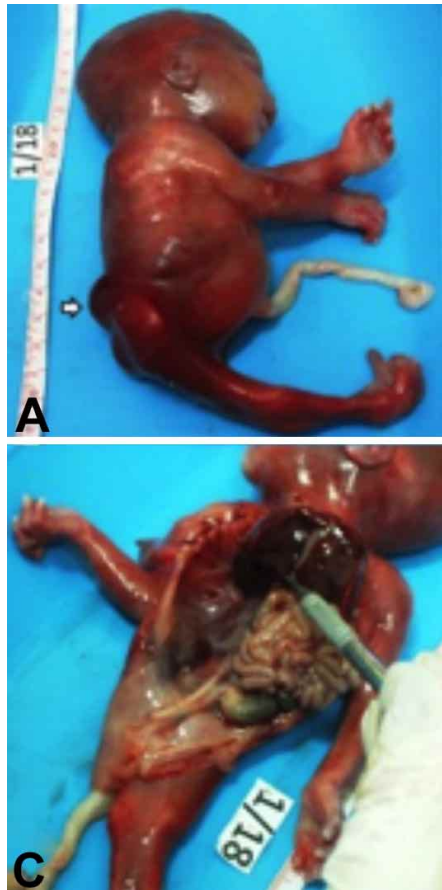

D
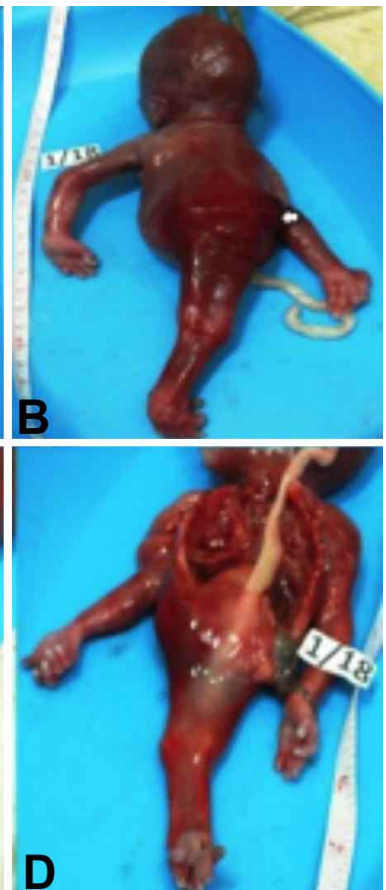

Fig. 2. Sirenomelia. A / Profile picture of the fetus. Cystic lumbosacral spina bifida (arrow), sirenomelia; B / Posterior view of fetus, Cystic lumbosacral spina bifida (arrow) and sirenomelia; $\mathrm{C}$ / agenesis of right phrenic dome, agenesis of the internal genitalia and bladder, blindly ending colon; D / Agenesis of external genitalia and sirenomelia.

Ethics Committee of the Medical University of Plovdiv (Protocol 5, 29.09.2016) and were in accordance with the Helsinki Declaration of 1975, as revised in 2000.

Implemented X-ray examination of the fetus confirmed MRI data for severe defects in the lower spine (Fig. 1 A,B). The fetopathological examination found fetal growth restriction (FGR), lumbo-sacral myelomeningocele, hydrocephalus, anal imperforation, single umbilical artery,

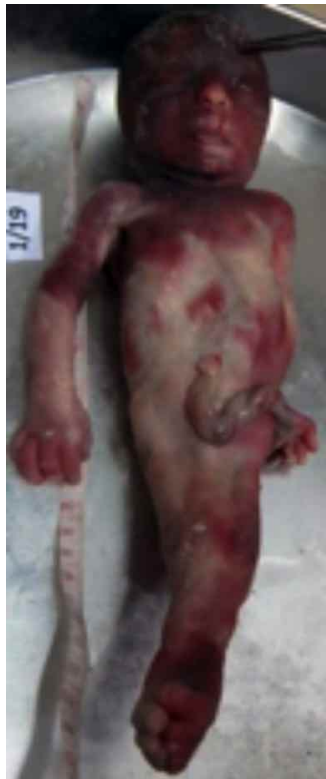

Fig. 3. Anterior view of the fetus: sirenomelia and agenesis of external genitalia.

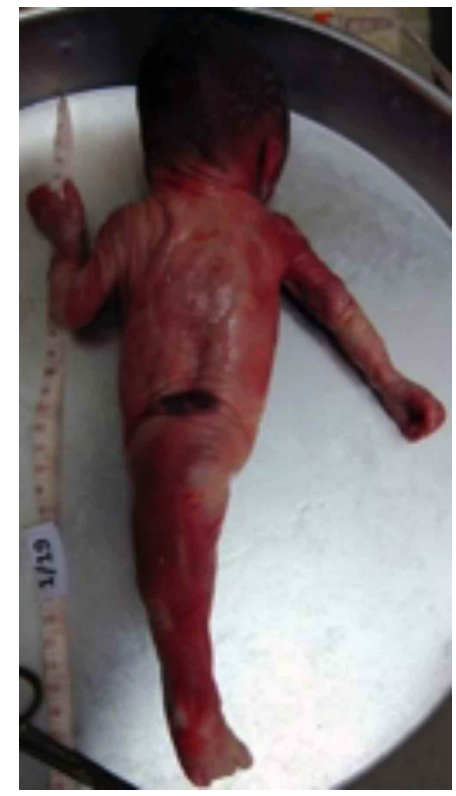

Fig. 4. Posterior view of the fetus sirenomelia, myelomeningocele and anal imperforation. bilateral renal and ureteric agenesis, bladder agenesis, tracheo-esophageal fistula, agenesis of external genitals, female internal genitals, monkey fold of the left palm of the hand, sirenomelia type I: (Fig. 2). Fetopathological diagnosis was sirenomelia with VECTERL - $\mathrm{H}$ association.

Case 2. Folic acid supplemented a woman at the age of 40, primigravida healthy eating, no bad habits and illnesses. There are no anomalies of this kind. During the 5th month of pregnancy she had bleeding and enters in the Clinic of Obstetrics and Gynecology, University Hospital "St. George ", Plovdiv, Bulgaria. A prenatal ultrasound examination 
revealed the presence of malformative syndrome, which is why a medical abortion was performed in $27 \mathrm{GW}$. The procedures followed were approved by the institutional Ethics Committee of the Medical University of Plovdiv (Protocol 5, 29.09.2016) and were in accordance with the Helsinki Declaration of 1975, as revised in 2000. The previous amniocentesis and genetic testing did not detect abnormalities.

Fetal necropsy reveals fetus with sirenomelia, agenesis of external genitalia, anal imperforation, spina bifida cystica, left preauricular skin tag (proboscis), dolichocrania, macroglossia, low set ears, long philtrum, lung hypoplasia, irregular lobulation, split cadiac apex, single umbilical artery, blind end colon, hepatic fibrosis, accessory spleen, polycystic horseshoe kidney, agnesis of the uterus and vagina, the presence of two ovaries and duodenal stenosis (Figs. 3 and $6)$.

X-ray showed sirenomelia type II, histological examination revealed renal polycystosis, cysts of the parenchymal organs, lung, liver, brain, spinal cord and heart (Figs. 7 and 8). The fetopathologic diagnosis was sirenomelia associated with VECTERL.

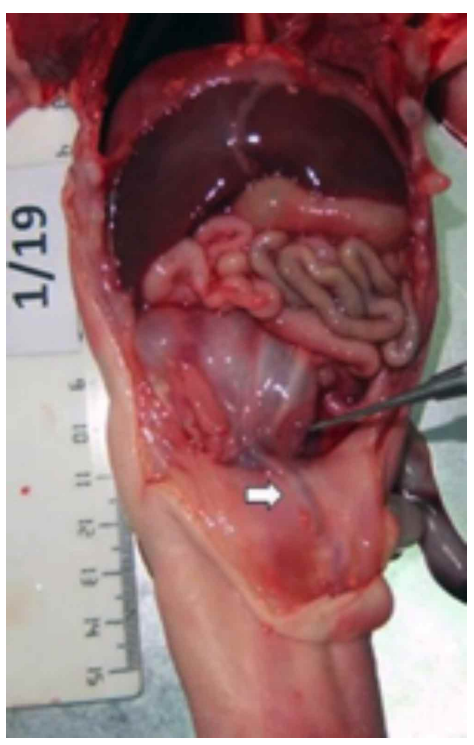

Fig. 5. Polycystic kidney, ovary and single umbilical artery (arrow).

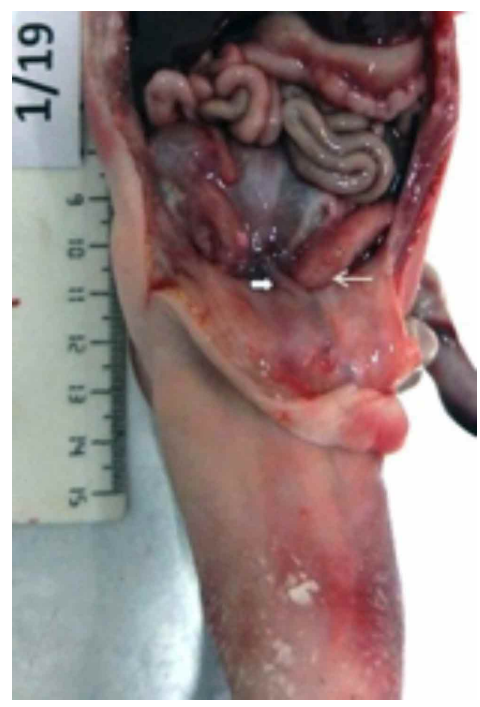

Fig. 6. Blind end colon (white arrow), bladder agenesis and single umbilical artery (black and white arrow).

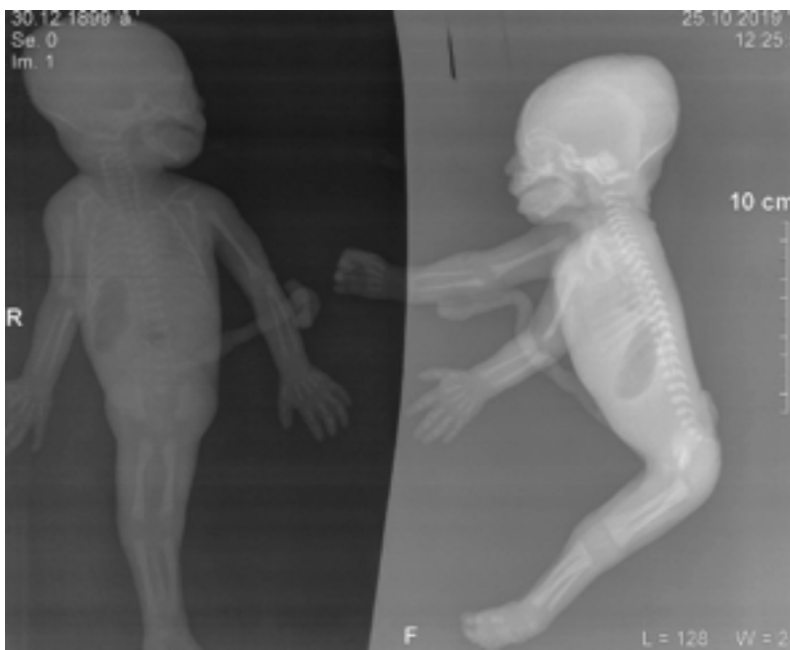

Fig. 7. Radiography (face and profile) - visualizes the single fibula and vertebral defects.
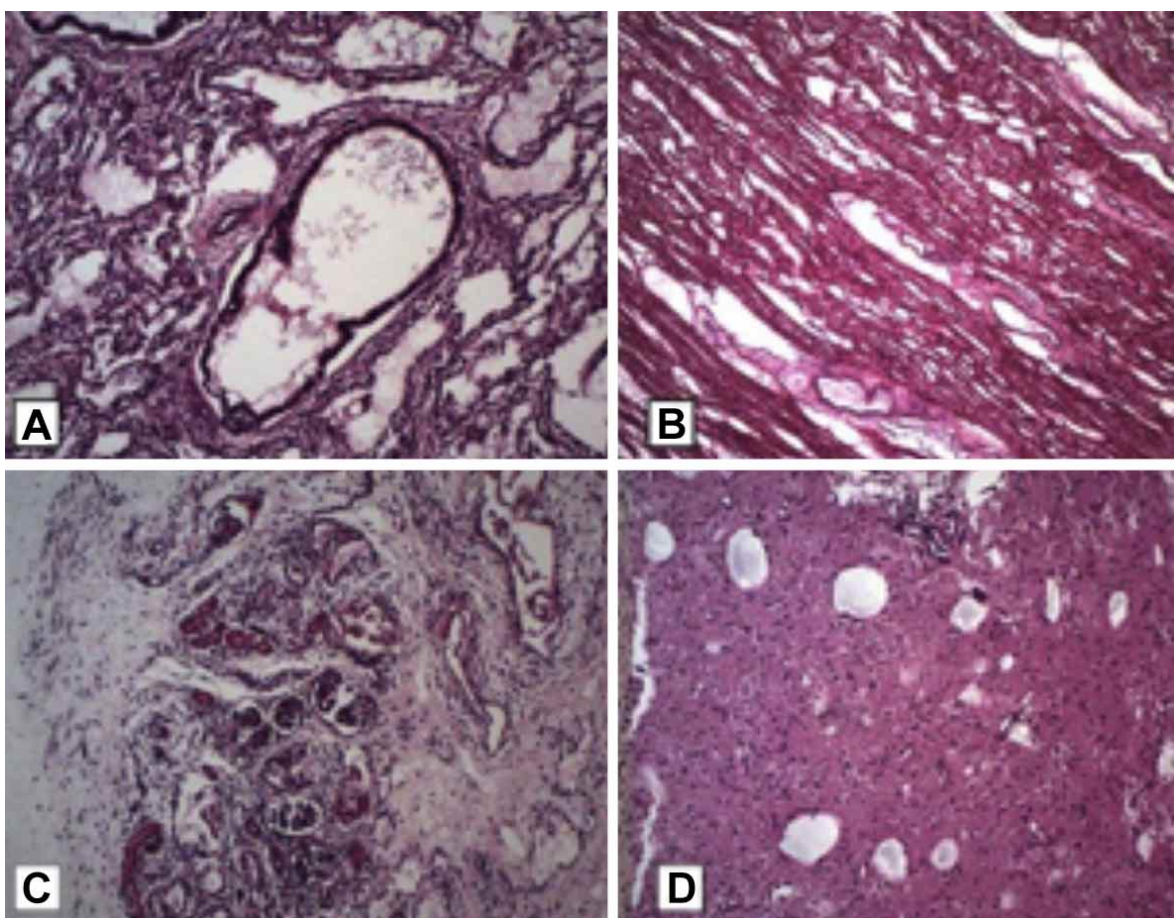

Fig. 8. Histological examination. A / cysts in the lungs; B / Myocardial cysts; C / Kidney cysts; $\mathrm{D} / \mathrm{Cysts}$ in the cerebral cortex. 


\section{DISCUSSION}

In the study of Isik Kaygusuz et al. the presence of single umbilical artery in cases of sirenomelia was found in $60 \%$ of cases, which is confirmed by our cases.

According to Orioli et al., the sex of fetuses with sirenomelia cannot be established in $46 \%$ of cases, whereas, according to Kirimi et al. (2010) the male sex is three times more than that of the female.

In both cases, there is agenesis of the external genitalia, but the fetopathology examination showed evidence of female internal genitalia.

Kallen et al. (1992) reported an increased risk of sirenomelia in fetuses worn by mothers under 20 and $\geq 40$ years of age, and this finding is not statistically significant. In their large epidemiological study, Orioli et al. noted an increased risk of sirenomelia at maternal age below 20 years. The maternal age in our two cases is 15 and 40 years, which confirms what Kallen et al., (1992) and Orioli et al. say.

Until recently, sirenomelia was considered to be the most severe form of caudal regression syndrome (CRS), but lately it is thought that they are two different anomalies with different embryonic origin (Tonni \& Grisolia, 2013). Both of them have common specific anomalies, but in addition to the fusion of the lower limbs, the presence of an aberrant umbilical artery / "persistent vitelline artery" is a major anatomical finding that distinguishes sirenomelia from CRS (Van Keirsbilck et al., 2006; Duesterhoeft et al., 2007). Caudal regression syndrome arises from a primary defect of the caudal mesoderm between the 28th and 32nd gestational days. Teratogenic agents during third GW may interfere with the formation of the notochord, leading to abnormal development of caudal structures (Van Keirsbilck et al.).

The occurence of sirenomelia has been reported in the literature by several mechanisms: caudal mesoderm deficiency due to impaired blastogenesis, mechanical defects resulting from lateral compression by amniotic folds, and trophic defects due to insufficient blood supply in the posterior region (Tonni \& Grisolia). The hypothesis of impaired blood supply to the caudal end of the embryo by vascular theft is the most likely cause of sirenomelia (Duesterhoeft et al.). According to it, abnormal vasa vitelina leads to a reduction of arterial blood flow to the caudal end of the embryo, whichdisrupts its normal development and causes aberrant formation of the lower limbs (Van Keirsbilck et al.; Duesterhoeft et al.).
Most fetuses with sirenomelia have impaired blood supply, because the umbilical artery associated with the upper mesenteric arteries.

According to another hypothesis, the caudal mesoderm is damaged during blastogenesis of the embryo, which causes complete malformation of the caudal part of the embryo (Turgut et al.).

Sirenomelia is a typical example of a primary blastogenesis defect affecting multiple primordial cells located around the middle line during the final stages of gastrulation at the level of the caudal eminence.

The caudal eminence is responsible for the production of mesenchyme for the lower limbs and perineum, somites and vertebrae until the closure of the most caudal neuropore.

Disruption of morphogenetic processes occurring at the level of the caudal eminence can lead to malformations of the sacrococcygeal vertebrae, various degrees of caudal dysgenesis, and sirenomelia (Opitz et al., 2002).

In experiments with mice, Garrido-Allepuz et al. (2011) determined genetic changes. Sirenomelia has been observed in mice lacking Cyp26a1, an enzyme that degrades retinoic acid (RA), which results in a reduction of signaling of the morphogenetic protein in the caudal part of the embryo. The phenotypes of these mutant mice suggest that sirenomelia in humans is associated with an excess of RA signaling and a deficiency of Bmp signaling in the caudal part of the embryo.

The most common central nervous system abnormalities reported in the literature are alobar holoprosocephaly and lumbar meningomyelocele, which is also confirmed by our cases in which myelomeningocele has been presented (Turgut et al.).

Many of the anomalies in fetuses with sirenomelia are identical to those associated with VA (C) TER / VACTERL associations. The VACTERL association occurs between 1 in 10,000 and 1 in 40,000 children, approximately <1-9 per 100,000 children and is an acronym for a combination of at least three of the following anomalies: vertebral defects $(\mathrm{V})$, anal atresia (A), heart defects (C), tracheo-esophageal fistula (TE), renal abnormalities (R), and limb defects (L) (Solomon, 2011). In some cases, the acronym extends to VACTERLS to include a single umbilical artery (Boer et al., 2007). There is little clinical and genetic evidence of heterogeneous etiology in patients with the VACTERL association. Genetic factors associated with the VACTERL association include mitochondrial dysfunction, chromosomal deletions or 
duplications, as well as mutations of the HOXD13, ZIC3, PTEN, FANCB, and FOXF1 genes (Chen et al., 2013). In addition to genetic causes, it is accepted that a small number of external and internal factors can also lead to the development of the disease, such as diabetes mellitus, long-term treatment for infertility, pregnancies worn in geographical areas near mines and groundwater (Ornoy et al., 2010).

The combination of VACTERL association with hydrocephalus was first described in 1984 and since then this state is described as VACTERL-H syndrome (Briard $e t$ al., 1984). A part of patients with the syndrome VACTERL$\mathrm{H}$ is established and associated with an $\mathrm{X}$ chromosome inheritance of anemia Fanconi, combined with a mutation of the FANCB gene (McCauley et al., 2011). Other patients with VACTERL-H syndrome have a lack of the combination of Fanconi anemia and chromosomal abnormalities, which is confirmed by our patient 1 .

Classically, sirenomelia has been isolated. The coexistence of sirenomelia with one or more features of the VACTERL association is possible but rare (Charlier et al., 2008).

Twenty cases of sirenomelia have been reported associated with multiple symptoms of VACTERL and only 2-3 with VACTERL-H (Onyeije et al., 1998; Duesterhoeft et al.; Vasisht et al., 2019).

In two of the six cases of Seidahmed et al. (2014) there are 5 of the 7 components of VACTERL without a trachea-esophageal fistula that may have been missed because no autopsy was performed.

The severity of anomalies in sirenomelia, especially in the gastrointestinal and urinary tract, may explain the presence of similar components in the VACTERL association (Seidahmed et al.). Lhuaire et al. (2013) describe a case of sirenomelia associated with the VACTERL association and Thomas syndrome characterized by renal and cardiac malformations and cleft lip or palate. Moosa et al. (2012) reported 4 cases of sirenomelia associated with the VACTERL association.

\section{CONCLUSION}

All these cases, including ours, lead us to believe that sirenomelia and the VACTERL association are probably different manifestations of a pathogenetic process leading to disorders of blastogenesis at different levels during embryonic development.
KITOVA, T. T.; UCHIKOVA, E. H.; UCHIKOV, P. A. \& KITOV, B. D. Sirenomelia asociada con síndrome de VACTERL y VACTERL-H. Int. J. Morphol., 38(3):793-798, 2020.

RESUMEN: La sirenomelia es una malformación congénita y excepcionalmente rara, con una frecuencia entre 1,5 y 4,2 en un millón de embarazos. La combinación de la sirenomelia con el síndrome de VACTERL es igualmente rara. La literatura especializada informa sobre la existencia de una veintena de casos solamente; en lo que respecta a su asociación con el síndrome de VACTERL-H se conocen solo dos casos. Luego de realizar una revisión de la literatura presentamos dos casos de sirenomelia asociada con los síndromes de VACTERL-H y de VACTERL En el estudio se analizaron los primeros embarazos de dos mujeres, edad de 15 y de 40 años, respectivamente, ambas mujeres completamente sanas y sin hábitos viciosos. Entre la vigésima quinta y la vigésima séptima semana gestacional (SG) del embarazo ambas mujeres, el análisis prenatal comprueba la existencia de malformación del feto debido a lo cual los embarazos fueron interrumpidos por prescripción médica. El análisis fetopatológico del primer caso comprueba la existencia de sirenomelia de tipo I asociada con mielomeningocele, hidrocefalia, atresia anal, arteria umbilical única, agenesia bilateral de los riñones y de los ureteres que transportan la orina desde los riñones hasta la vejiga, fístula traqueoesofágica, agenesia de los órganos genitales externos, línea simiesca en la palma de la mano izquierda - VACTERLH. En el segundo caso, en que el análisis genético ha resultado normal, se observó la presencia de sirenomelia de tipo II asociada con agenesia de los órganos genitales externos, atresia anal, mielomeningocele, dolicocrania, macroglosia, orejas bajas, filtrum alargado, hipoplasia pulmonar, ápice cardíaco escindido, arteria umbilical única, colon terminado en ciego, bazo accesorio, poliquistosis renal, riñón en herradura, agenesia vaginal y de útero, presencia de dos ovarios y estenosis duodenal - VACTERL asociación. Los dos casos investigados permiten llegar a la conclusión de que la sirenomelia y su combinación con el síndrome de VACTERL probablemente sean manifestaciones diferentes de un proceso patogenético que conlleva la alteración de la blastogénesis en distintos niveles durante el proceso del desarrollo embrionario.

PALABRAS CLAVE: VACTER; Asociación; VACTERL-H; Sirenomelia; Desarrollo embrionario; Estudios genéticos; Malformación congénita.

\section{REFERENCES}

Boer, L. L.; Morava, E.; Klein, W. M.; Schepens-Franke, A. N. \& Oostra, R. J. Sirenomelia: a multi-systemic polytopic field defect with ongoing controversies. Birth Defects Res., 109(10):791-804, 2017.

Briard, M. L.; le Merrer; Plauchu, H.; Dodinval, P.; Lambotte, C.; Moraine, C. \& Serville, F. Association of VACTERL and hydrocephalus: a new familial entity. Ann. Genet., 27(4):220-3, 1984.

Charlier, P.; Valat, A. S.; Boutec, O.; Petit, S.; Chafiotte, C.; Huynh-Charlier, I.; Gosselin, B. \& Devisme, L. Sirénomélie entrant dans le cadre d'une association VACTERL : à propos de trois cas. Ann. Pathologie., 28(3):176-81, 2008. 
Chen, C. P.; Chang, T. Y.; Chen, Y. Y.; Chern, S. R.; Su, J. W. \& Wang, W. VACTERL association with hydrocephalus in a fetus conceived by in vitro fertilization and embryo transfer. Taiwan. J. Obstet. Gynecol., 52(4):575-9, 2013.

Duesterhoeft, S. M.; Ernst, L. M.; Siebert, J. R. \& Kapur, R. P. Five cases of caudal regression with an aberrant abdominal umbilical artery: Further support for a caudal regression-sirenomelia spectrum. Am. J. Med. Genet. A, 143a(24):3175-84, 2007.

Garrido-Allepuz, C.; Haro, E., González-Lamuño, D.; Martínez-Frías, M. L.; Bertocchini, F. \& Ros, M. A. A clinical and experimental overview of sirenomelia: insight into the mechanisms of congenital limb malformations. Dis. Model. Mech., 4(3):289-99, 2011.

Isik Kaygusuz, E.; Kurek Eken, M.; Sivrikoz, O. N. \& Cetiner, H. Sirenomelia: a review of embryogenic theories and discussion of the differences from caudal regression syndrome. J. Matern. Fetal Neonatal Med., 29(6):949-53, 2016.

Källén, B.; Castilla, E. E.; Lancaster, P. A.; Mutchinick, O.; Knudsen, L. B.; Martínez-Frías, M. L.; Mastroiacovo, P. \& Robert, E. The cyclops and the mermaid: an epidemiological study of two types of rare malformation. J. Med. Genet., 29(1):30-5, 1992.

Kirimi, E.; Peker, E.; Tuncer, O.; Akgün, C. \& Kurdolu, Z. Concurrence of sirenomelia and polydactyly: A case report. Anatol. J. Clin. Invest., 4(1):67-9, 2010

Lhuaire, M.; Jestin, A.; Boulagnon, C.; Loock, M.; Doco-Fenzy, M.; Gaillard, D.; Diebold, M. D.; Avisse, C. \& Labrousse, M. Sirenomelia: a new type, showing VACTERL association with Thomas syndrome and a review of literature. Birth Defects Res. A Clin. Mol. Teratol., 97(3):123-32, 2013.

McCauley, J.; Masand, N.; McGowan, R.; Rajagopalan, S.; Hunter, A.; Michaud, J. L.; Gibson, K.; Robertson, J.; Vaz, F.; Abbs, S.; et al. Xlinked VACTERL with hydrocephalus syndrome: further delineation of the phenotype caused by FANCB mutations. Am. J. Med. Genet. A, 155A(10):2370-80, 2011.

Moosa, S.; Lambie, L. A. \& Krause, A. Sirenomelia: four further cases with discussion of associated upper limb defects. Clin. Dysmorphol., 21(3):124-30, 2012.

Onyeije, C. I.; Sherer, D. M.; Handwerker, S. \& Shah, L. Prenatal diagnosis of sirenomelia with bilateral hydrocephalus: report of a previously undocumented form of VACTERL-H association. Am. J. Perinatol., 15(3):193-7, 1998.

Opitz, J. M.; Zanni, G.; Reynolds Jr., J. F. \& Gilbert-Barness, E. Defects of blastogenesis. Am. J. Med. Genet., 115(4):269-86, 2002.

Orioli, I. M.; Amar, E.; Arteaga-Vazquez, J.; Bakker, M. K.; Bianca, S.; Botto, L. D.; Clementi, M.; Correa, A.; Csaky-Szunyogh, M.; Leoncini, E.; et al. Sirenomelia: an epidemiologic study in a large dataset from the International Clearinghouse of Birth Defects Surveillance and Research, and literature review. Am. J. Med. Genet. C Semin. Med. Genet., 157C(4):358-73, 2011.

Ornoy, A.; Rand, S. B. \& Bischitz, N. Hyperglycemia and hypoxia are interrelated in their teratogenic mechanism: studies on cultured rat embryos. Birth Defects Res. B Dev. Reprod. Toxicol., 89(2):106-15, 2010.

Seidahmed, M. Z.; Abdelbasit,. O. B.; Alhussein, K. A.; Miqdad, A. M.; Khalil, M. I. \& Salih, M. A. Sirenomelia and severe caudal regression syndrome. Saudi Med. J., 35 Suppl. 1:S36-43, 2014.

Solomon, B. D. VACTERL/VATER association. Orphanet J. Rare Dis., 6:56, 2011.

Stocker, J. T. \& Heifetz, S. A. Sirenomelia. A morphological study of 33 cases and review of the literature. Perspect. Pediatr. Pathol., 10:7-50, 1987.

Tonni, G. \& Grisolia, G. Sirenomelia: a review on embryogenic enviromental theories, novel three-dimensional ultrasound imaging and first trimester diagnosis in a case of mosaic 69,XXX/46,XX fetus. Arch. Gynecol. Obstet., 288(1):3-11, 2013.

Turgut, H.; Ozdemir, R.; Gokce, I. K.; Karakurt, C. \& Karadag, A. Sirenomelia associated with hypoplastic left heart in a newborn. Balkan J. Med. Genet., 20(1):91-4, 2017.
Van Keirsbilck, J.; Cannie, M.; Robrechts, C.; de Ravel, T.; Dymarkowski, S.; Van den Bosch, T. \& Van Schoubroeck, D. First trimester diagnosis of sirenomelia. Prenat. Diagn., 26(8):684-8, 2006.

Vasisht, P.; Madakshira, M. G.; Kakkar, N.; Singla, V. \& Jain, V. Tale of a mermaid. Indian J. Pathol. Microbio., 62(4):611-3, 2019.

\author{
Corresponding author: \\ Tanya T Kitova \\ Department of Anatomy \\ Histology and Embryology \\ Medical University - Plovdiv \\ «Vasil Aprilov» Str. 15A \\ 4002 Plovdiv \\ BULGARIA
}

Email: tanyakitova@yahoo.com

Received: 24-01-2020

Accepted: 15-02-2020 